\title{
The impact of oil export fluctuations in the gross domestic product: Analytical study on the Libyan economy (Through the period 2008-2018)
}

\author{
Iman Elhusadi \\ Economic department \\ University of Omar Mukhtar \\ Albida/ Libya \\ DOI: 10.31364/SCIRJ/v7.i4.2019.P0419639 \\ http://dx.doi.org/10.31364/SCIRJ/v7.i4.2019.P0419639
}

\begin{abstract}
The study aims to analyse the reality of oil exports (oil crude, oil derivatives and natural gas) and their contribution to the growth of gross domestic product during the period 2008 to 2018 by tracking the economic indicators that reflect the chan ges occurred as a result of the Arab Spring revolutions (the Libyan revolution as model). We tried to determine the state of the national economy, where the researcher concentrated on GDP, and the oil exports through tracking the indicators issued by the Planning Secretariat, and the National Information and Documentation Authority, the annual publications and reports of the Libyan Central Bank. We used the descriptive analytical approach. Our study demonstrated that during the years 2008-2018 the country witnessed a contraction in economic activity, as the political unrest in Libya has negatively impacted on economy, and it caused a 70\% drop in oil and gas production. This decline played an important role in the decline of exports of oil and natural gas in the Libyan economy. The important result of the study is the oil sector plays a vital and important role in the Libyan economy as it is the main source of income, foreign exchange returns, financial revenues, and these fluctuations in oil sector led to lower GDP.
\end{abstract}

Keywords: Gross Domestic Product, oil exports, Oil crude, Natural gas, Economy, Fluctuations

\section{INTRODUCTION}

The Libyan economy witnessed drastic changes when the oil was discovered in the late 1950s and the early 1960s and a shift of economy from the agricultural economy to an oil economy depending on this commodity, and Libya moved from one of the world's poorest countries to a country has natural resources in a way that enables it to direct its oil revenues to ambitious development programs. Despite the overall objective of the development strategy directing these revenues to other productive sectors in an attempt to create alternatives to the oil sector, the Libyan economy has not been able to free itself from the control of the oil sector, which still controls the bulk of economic activity in Libya and thus the economy is exposed to the instability resulting from its adoption of one commodity depleted and to the fluctuations in its prices and conditions of its production. The oil sector is the most important sector in the Libyan economy, as it is the main source of income in addition to being the highest percentage in the composition of GDP, and GDP is one of the important indicators of economic growth. Oil receipts dominate the economy: according to the IMF, where oil accounts for more than $90 \%$ of fiscal revenue, a share higher than in any other Arab oil-exporting country. Non-oil exports of goods and services are under 3\% of total GDP, according to the most recent data available. This paper focuses on the concept of Libyan oil exports Which affected negatively on economic variables through riots and civil wars in the Arab world that have begun in late 2010 in Tunisia and then spread a wave of protests to many Arab countries, which played an important role in economies of these developing countries including Libya. This important role is reflected in the impact on government revenue, prices, exports, imports, economic growth, the balance of payments and the general welfare of the state. The researcher focuses on fluctuations in Libyan oil exports and their negative impact on real GDP. 


\section{The problem of the study}

In spite of Libya's previous attempts to diversify the structure of exports and increase the production base (industrial and agricultural), the Libyan economy relied mainly on the export of one commodity through which gets foreign currencies, which are the main source to finance, and spending on the rest of the economic sectors, in addition to this commodity linked to conditions of global demand and supply, and external factors outside of the control in Libyan economy such as the political turmoil, not to mention the role of some organizations in the determination of oil prices and the most important the OPEC. And as long as the Libyan economy depends on oil and its revenues so, the revolution in Libya and its political and security implications led to the declined and even cessation of oil production completely, so affected the volume of oil exports and the proportion of these exports to the gross domestic product. Here the problem of the study in the answer to the following question of whether the fluctuations in oil exports was reflected in GDP?

\section{The hypotheses of the study}

The hypothesis of the study is in the form of the following question: Is the fluctuations of the oil exports reflected negatively on the Libyan economy especially on GDP as a result of the Global volatility and the Arab Spring revolutions.

\section{The importance of the study}

The importance of the study set out from tackling the problem of adopting the Libyan economy on a single commodity that is depleted, which makes the economy fraught with risks because it was influenced by several factors such as war and current political turmoil political disturbances. so the importance of the study lies in shedding light on the oil exports and their effect on GDP of the Libyan economy, Therefore, it is necessary to devise strategies to develop other economic sectors and diversify of Production base.

\section{The objective of the study}

The study aims to analyze the impact of volatilities of oil exports on the GDP during the period under study to confirm the extent of the dependence of the Libyan economy on the export of one depleting commodity and the consequent risks to the Libyan economy and on the gross domestic product.

\section{The methodology of the study}

The researcher used the analytical descriptive method through the use of some indicators used to determine the relationship between oil and non-oil exports by GDP, reaching to the degree of dependence of the national economy on oil exports. And the extent to which GDP is affected by fluctuations in oil exports as a result of the political turmoil experienced by the state.

To achieve the research objectives, the study will be divided into two aspects

The theoretical aspect in this regard, we will shed light on the conceptual framework of the export and its types, the concept of Gross Domestic Product and its types, we will display the risks of adopting the Libyan economy on a single commodity, and we will offer the reality of Libyan exports of oil during the study period depending on economic indicators issued by the Libyan Central Bank. The analytical side will include the study and analyse of the development of exports of oil wealth (crude oil and natural gas) and its derivatives, in addition to the study of the impact of oil export fluctuations on GDP during the period 20082018.

\section{7. limits of the study:}

1- The Spatial limits: is represented in the Libyan economy. 
2- The temporal limits: The main focus is on the period between (2008-2018).

3-Objective limits include identifying the impact of the fluctuations of the oil exports on the Libyan GDP by focusing on the indicators of the GDP and oil exports as the most important indicators that reflect the reality of the Libyan economy.

\section{Literature review}

Many previous studies have indicated that the relationship between growth in real GDP as an indicator of economic growth and exports in general may be direct or indirect, but the increase in exports has a positive effect on GDP and hence economic growth. Shamia, A. A. (1991) show that through their study that entitled as Libyan exports and its role on the economy: Applied theory study (1980-1990). The study focused on the relationship between foreign trade and economic growth, an analysis of the reality of Libyan exports and the commodity composition of exports during 1990. The study reached results, the most important of which was the control of oil exports on with an average of $79 \%$ during the study period and non-oil exports averaging $3 \%$ over the same period. Abu Ghalia, M, S. \& Al-Fahal, H. (2012) study was an analytical study during the period 1995-2008. Researcher attempt to study the oil exports relationship to the rate of the economy's openness with the outside world: The researchers discussed that the most important result is that the exports of Libya were concentrated on crude oil that means the increase of the openness of the Libyan economy to the outside world. This, in turn, increases the degree of vulnerability of the Libyan economy to the external factors, which are certainly beyond the control of the Libyan economy. Yahia, A. \& Metwally, M. M. (2007), two researchers used exports as a major driver of economic growth, the study uses a Koyck distributed lag scheme and the researchers also used the cointegration analysis to study the long-term relationship between Libya GDP and its oil exports, the paper reached to the result that the effects spread from oil exports to the rest of the economy, and inflationary effects were excluded. In addition, results of cointegration analysis suggest that there is no long-term relationship between Libyan oil exports and non-oil GDP. Vohra (2010) discussed the relation between exports and economic growth, and the researcher concluded the exports benefit the GDP, improve utilization of capacity, raise specialization. Elbeydi, K; Hamuda, A M. and Gazda, V. (2010) also attempted to investigated the relationship between exports and economic growth in Libya, in their study, an econometric model has been developed and estimated in order to determine the direction of causality in both, short and long run through the time period 1980 - 2007. The results indicated that the income, exports, and relative prices are cointegrated, and the long-run bidirectional causality between the exports and income growth has been also proved. The researchers indicate that the Libyan export promotion policy contributes to the economic growth in it. Ahmouda, M. (2014) his study has focused upon the role of oil export and it is an effect on economic growth in Libya. He emphasized that the oil industry has an imperatively significant role in the Libya economy and it is the basic revenue source of Libya. Its economy entirely relies on this sector.

\section{1. conceptual framework}

1-1. The export concept: defined as those the goods and services traded outside the borders of the State for international markets and are intended to obtain foreign currencies, and they are two types of export visible and invisible.

\section{1-1-2. Types of the exports:}

> Visible exports of commodities: which include exports of physical goods that cross customs borders under the consideration of customs authorities, visual exports can be seen by the naked eye and touched by hand and are in the form of electronic products, crude oil, clothing etc.

$>$ Invisible exports of commodities: These are exports of intangible goods in human hands and cannot be seen with the naked eye in the form of services such as transportation services, insurance, tourism, banking services, investment services, etc. 


\section{1-2. The Gross Domestic product concept:}

The value of GDP (or national) is an important economic indicator that measures the ability of the national economy to produce goods and services. Any economy in the world produces many different commodities as well as many services. When we give cash value to these goods and services produced by an economy for a certain period of time, the sum of these values is expressed with gross domestic product. Gross domestic product (GDP) is an inflow because it reflects the output of goods and services over a given period of time, and increasing the volume of GDP from one year to another means an increase in the goods and services produced by the economy. In turn, it means increasing the employment opportunities of the community members, which increases their incomes, increases their consumption and increases investment Which will increase production again and so on, and vice versa. Is the monetary value of all goods and services produced in an economy over a given period of time, usually a year, in the previous definition, it is noted that GDP expresses the monetary value (market). This means that the value of goods and services is estimated in terms of prevailing prices during the evaluation period. It is calculated in a geographical area as an independent entity called a State, with its own independent economy, it is within this context that the production of a non-Libyan worker working in Libya as a foreign worker whose production falls within the GDP accounts of Libya, as well as for a Libyan investor who owns a factory in another country, the production of that plant is included in the GDP of that country within a certain period of time.

\section{1-2-1. Kinds of gross domestic product (GDP) :}

Nominal GDP: Defined as GDP that is evaluated at current market prices (GDP at current factor cost), the calculation of market price changes at present that includes any changes in market prices during the current year due to inflation or deflation.

$>$ Real GDP: is a more accurate indicator of economic performance and used to compare economic output from year to year while excluding the impact of inflation, and It is calculated based on fixed prices or value.

$>$ GDP per capita :This type is the ideal way to measure an individual's well-being or standard of living in each country because it gives a more accurate picture. It can be calculated by dividing the gross domestic product of a State by the population of that State.

2. Libyan oil exports: The excess Libyan oil sending to other countries across the border to earn foreign exchange.

\section{2-1. Kinds of Libyan oil export:}

Crude oil exports: Libyan crude oil is of Brent(blend) quality used as a standard for world's crude oil benchmark prices in the world oil market. Brent blend crude oil is of the highest quality and is found in oil wells of the North Sea off the coast of Britain and Norway, in Nigeria, in Libya, etc.

Natural Gas: Libyan natural gas production and export that was temporarily disrupted by the civil unrest of 2011. As with its oil sector, Libya's natural gas industry is recovering from disruption related to the civil unrest and political upheaval that began in 2011. Most of its natural gas production is exported, almost entirely to Italy via pipeline.

$>$ Petrochemical products: It consists of Libyan petroleum products which locally produced, such as liquid gas, benzene 95, kerosene, diesel fuel, heavy fuel oil, and aviation gas, as it is locally manufactured and exported to abroad and some consumed locally as well. Domestic production of petrochemicals has been affected and decreased due to the decline in the security and political conditions that the country is going through, which has negatively impacted the production levels, which led to a decrease in the quantities of crude oil available for refining and production of these derivatives. 


\section{2-2. The risks of adopting the Libyan economy on oil exports:}

Oil exports are affected by several factors, the most important of which are oil prices, the factors influencing it and the conditions of international demand and supply, As well as the deterioration of the security situation and the destruction of infrastructure as a result of the war in Libya all these factors led to a decline in production of crude oil and natural gas, which led to the exposure of the Libyan economy to a range of risks resulting from the dependence of the economy on one depleted commodity. There are several risks that result from the adoption of the Libyan economy on one depleted commodity, which is the oil, we will offer from it the following (Imhanna, M. E. 2016):

1-Risks result of wars and political crises: The oil sector is the pioneer sector of the Libyan economy and is the main engine for the rest of the economic sectors, where its revenue depends on oil revenues, It is natural that wars, political differences, and economic boycotts affect the Libyan economy and lead to its deterioration and collapse, The political crisis experienced in the Libyan state in 2011 and its aftermath of political conflicts led to the decline of the Libyan economy and the damage of all its sectors and the deterioration of oil production as a result of the exit of all foreign companies operating in the oil sector and the deterioration of the exchange rate, the inflation rate increased in October 2011 to 30\% This is because the Libyan economy depends on the oil sector, which accounts for more than $70 \%$ of the GDP and more than $95 \%$ of the total exports, The economy has not exceeded its crisis at the time only after the return of the foreign companies such as Eni of Italy, Total of France, the United States' Occidental, Spain's Repsol, and the economic performance became positive, but soon the economy became imbalanced by the outbreak of war in 2014 and the burning of some oil fields.

2- Risks arising from global crises: The effects of the global financial crisis in 2009 reflected in most of the world's economies, as well as oil-dependent countries and members in the organization of Arab petroleum exporting countries(OPEC), where oil revenues accounted for a large proportion of the GDP of these countries and its oil exports accounted for more than half the value of total commodity exports. The oil exporting countries were affected by this crisis and it reflected on their gross domestic products and oil exports, where these countries suffered from the problem of unemployment and inflation, and the decline in oil prices in 2009 as a result of the global crisis led to exacerbating the problem of inflation, negatively affected in the general budget and growth rates decreased in all sectors, major valley the decline in demand for oil to reduce opportunities for investment in the oil sector, among the countries affected by the global crisis Libya, Algeria, Angola and Niger, whose economies were linked to the economies of advanced industrial countries, and are members in OAPEC.

3- The risks resulting from the volatility of oil prices in the global oil market: The dependence of the Libyan economy on oil exports makes it vulnerable to fluctuations in the world oil market, and the increasing dependence on oil revenues will lead to instability and fluctuation in the economy because oil revenues are the only source of foreign currency, and given the major attribute of the Libyan economy it's depending on oil ,so the prices of oil exports are an important indicator In influencing the financing of development programs. Since the oil exports are directly linked to the global demand for oil and the factors affecting it and its prices, so the excess supply of oil in the global market in the eighties led to lower prices until the collapse, that led to Libya's crude oil revenues fell from \$ 41 in 1981 to \$ 9.63 in 1986 and continued to decline until 1989. The price of oil reached \$ 10.13 per barrel. This led to the inability of the state to play a major role in the development process. However, the increase in oil prices to record a record in 2006 to reach (70) dollars a barrel role in increasing the revenues of the state, which led to increased spending in development projects in that period and was focused on new development projects alternative to the oil sector to form GDP for the benefit of activities and sectors Oil exports such as tourism and the promotion of non-oil export industries, but oil exports still dominate the Libyan economy, accounting for $96.3 \%$ in 2004 of total exports and the risk of dependence of the Libyan economy on this economy and exports. 
4-Risks of economic subordination to developed countries: The economic independence of the state lies in the state's control of its natural resources in terms of extraction and production But because of the weakness of the capabilities of mankind and the material potential of developing countries including Libya, that makes it in depending on developed countries, and in addition, the economic independence of oil-exporting countries in controlling their wealth is linked to international and domestic support, but did not receive this support at many times, Where the oil companies of Western oil-importing countries managed to extend their control over the oil industry in developing countries in 1973, which enabled them to control prices and production to serve their interests. And this reflected in the terms of trade between the countries exporting and importing oil, is not in advantaging of oilexporting countries and this made many oil countries, including Libya, lose much of its oil revenues on imports from the industrial countries importing oil and here highlights the danger of the continued oil developing countries to rely on oil revenues that the global market dominates on their prices. On the other hand, despite the dependence of Libya on oil revenues to finance economic development projects, these revenues have not contributed to the development of other economic sectors except in a very limited way. The control of foreign companies on the modern technology in the oil sector made it developed and separated from other economic sectors lagging behind, which brought about an imbalance economic between the sectors, especially the agricultural and industrial sectors. Thus, the contribution of the two sectors to the gross domestic product has deteriorated. In addition, and the foreign trade sector has increased as a percentage of the gross domestic product clearly as a reflection of the state of openness which shows Libyan economy is dependent on the outside to provide its basic needs, which confirms the lack of economic independence, in addition to the non-elasticity of exports and its link to the international oil market.

5- The risks of going to alternative energy sources: The dependence of the Libyan economy on oil revenues in building its economic structures and financing its development projects makes it in danger of finding alternative sources of energy. The emergence of the energy crisis in the major industrial countries importing oil resulting from OPEC's raising the price of oil in the global market led to the industrial countries to think about alternative energy sources such as solar energy and the replacement of gas, coal and nuclear power. Therefore, the reaction of the Western countries importing oil requires the oil countries, including Libya, the need for serious and inevitable research on alternative sources of income of oil.

6- Risks arising from balance of payments deficit and trade balance: The trade balance is known as a record of transactions commodities between those residing in a particular country on the one hand and those residing in the rest of the world on the other hand. A balance of payments is a larger record include the exchange of funds and services. The Surplus in the trade balance reflects the strength of the country's economy, while the deficit reflects the weakness of the country's economy. The Libyan economy is one of the oil economies (rent), which depends on the revenues of oil exports and these exports are hostage to the conditions of the international oil market, so the trade balance in Libya was characterized by the rotation of deficit and surplus over the past decades, However, the surplus was a predominant feature of Libya's relations with the outside world due to oil exports. In the 1980s, the deficit occurred as a result of the global oil market crisis of that period, as well as the deficit during the nineties because of the economic embargo imposed by the European countries on Libya, However, this deficit was of limited value and low compared to surplus values.

7- The risks resulting from the conversion of oil revenues abroad: Instead of investing oil revenues in productive projects in the agricultural and industrial sectors and use the local labour in which provides the opportunity to eliminate unemployment and allow the use of economic resources and local production requirements to support the national economy. In addition to the use of part of those proceeds in the establishment of rehabilitation centres and training for personnel to increase their efficiency and productive capacity, but this has not happened in the Libyan economy, Where the Libyan economy was characterized by weak absorptive capacity of investments. Therefore, the investment of revenues from oil exports turn to abroad despite the issuance of Law No. 5 ) and its amendments on the promotion of investment however that most of the inside investments in oil revenues were directed to the oil sector and was in favour of developed countries, and therefore had a negative and serious effects on the 
Libyan economy and caused distortions in infrastructure Of the Libyan economy that represented by a phenomenon of the duplication, and this confirms the risks of dependence of the Libyan economy on its oil revenues.

8- Risks resulting from depletion of oil reserves and high production costs: The continuous extraction of oil means depletion of its resources, As the exploration process research for oil will require huge amounts and costs and sometimes fail; This requires mobilizing large sums of money to compensate for one barrel extracted from the ground. Oil wealth can generate a large inflow of sustainable income for the national economy Although oil is a depleted wealth, sound financial management can shift enforceable income into unlimited and long-term annual income that through oil revenues in support of non-oil growth in sectors Other productivity to ensure the face of fluctuations and oil shocks.

\section{2-3. Overview of Libyan Oil exports}

The developing of Libya's GDP, which is the most important indicator of economic growth, is determined by oil exports, so Libyan's economy is heavily dependent on oil production. In 1956, the first concessions were granted for oil exploration. In 1958, the first successful discovery of the country's largest oil fields was the Zletin and Amal oil fields by ESSO Libya. The Libyan economy shifted from a poor agricultural economy to an oil export-dependent economy, and the first export operation was in 1961. Libya joined the Organization of Petroleum Exporting Countries (OPEC) in 1961 after the first oil export operation. And developing countries members of OPEC are: Ecuador, Gabon, Algeria, Iran, Indonesia, Iraq, Kuwait, Libya, Nigeria, Qatar, Saudi Arabia, Unit Arab Emirates, and Venezuela. Libya has the largest amount of proven crude oil reserves in Africa and the fifth largest proven reserves of natural gas, and in past years Libya was an important contributor to the global supply of crude oil (light, sweet), (low sulphur), which Libya mostly exports to European markets, and the following map shows oil crude and natural gas infrastructure in Libya:

Figure 1. Map of oil crude and natural gas infrastructure in Libya

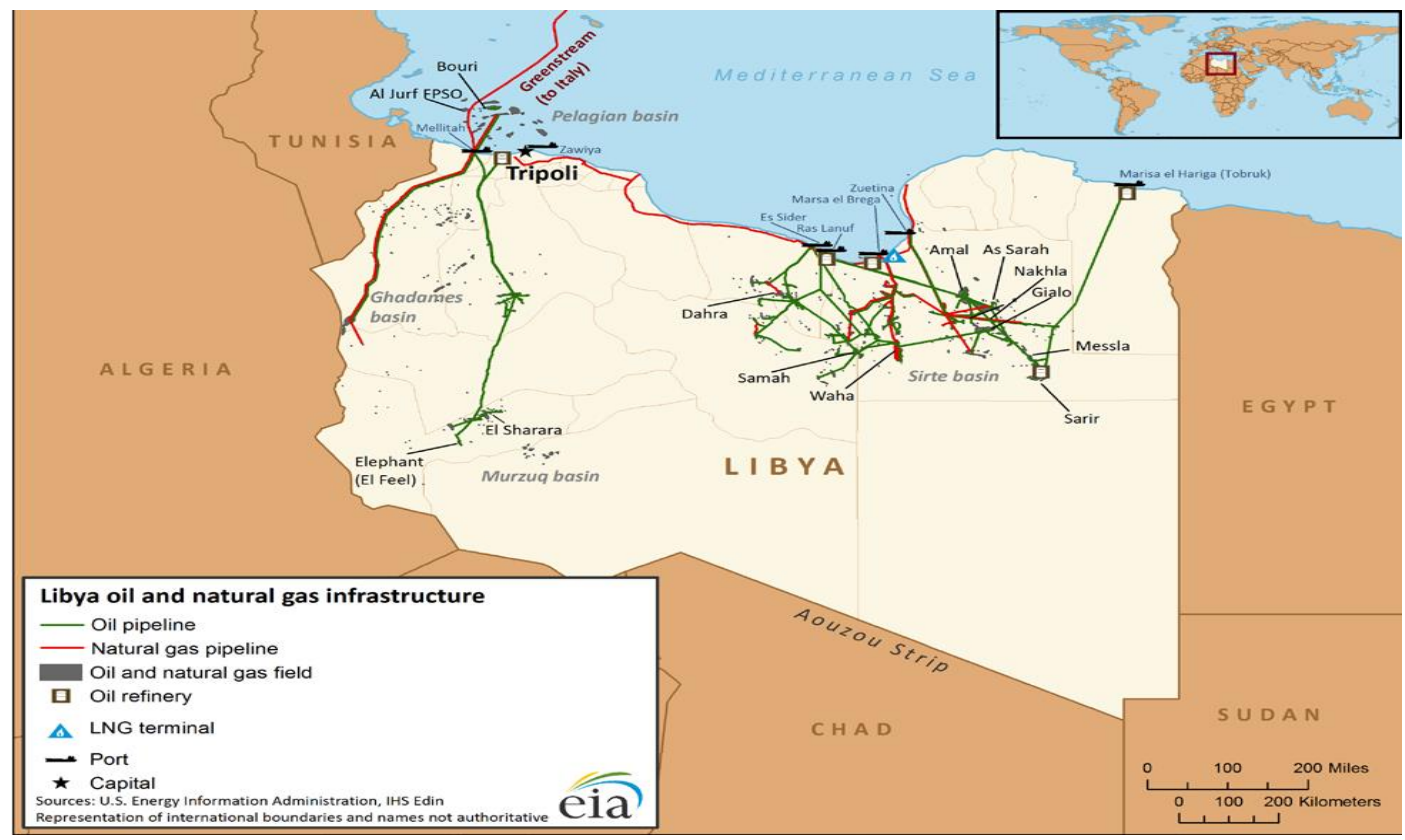

Libya holds six large sedimentary basins that are: Ghadames, Cyrenaica, Sirte, Murzuk, Kufra, and the basins offshore. Libya's recoverable reserves about $80 \%$ in Sirte basin which also represents for most of the country's oil production capacity. In addition to most of Libya's oil remains unexplored because civil unrest in 2011 has prevented large-scale exploration programs (U.S. Energy Information Administration,2015).

\section{2-4. Geographical distribution of Libyan oil exports}


According to the table (1) and data available through the Economic Bulletin issued by the Central Bank of Libya for the year 2018 which including the period (2008-2017), we will present the geographical distribution of Libyan exports as following:

Table (1) show Geographical Distribution of Exports through period (2008-2018)

Millions of U.S Dollars.

\begin{tabular}{|c|c|c|c|c|c|c|c|c|}
\hline & 2010 & 2011 & 2012 & 2013 & 2014 & 2015 & 2016 & 2017 \\
\hline Total Exports & 53,651 & 21,330 & 65,305 & 46,862 & 24,369 & 14,315 & 9,139 & 18,433 \\
\hline Advanced Economies & 44,385 & 16,241 & 52,160 & 39,277 & 21,359 & 10,997 & 5,806 & 13,740 \\
\hline $\begin{array}{l}\text { The proportion to } \\
\text { total exports }\end{array}$ & $83 \%$ & $76 \%$ & $80 \%$ & $84 \%$ & $88 \%$ & $77 \%$ & $64 \%$ & $75 \%$ \\
\hline Euro Area & 37,703 & 13,856 & 41,220 & 29,759 & 18,045 & 10,198 & 4,776 & 10,770 \\
\hline Italy & 14,437 & 4,869 & 15,194 & 9,464 & 6,929 & 4,760 & 2,216 & 3501 \\
\hline France & 7,266 & 3,039 & 6,314 & 4,906 & 2,846 & 1,185 & 709 & 2020 \\
\hline Spain & 5,083 & 1,111 & 4,935 & 2,938 & 1,293 & 829 & 865 & 2301 \\
\hline Germany & 4,697 & 3,052 & 8,084 & 7,084 & 2,593 & 1,675 & 338 & 1581 \\
\hline Belgium & 63 & 104 & 81 & 65 & 18 & 30 & 8 & 25 \\
\hline Austria & 1,134 & 450 & 931 & 714 & 912 & 498 & 21 & 25 \\
\hline Portugal & 1,119 & 21 & 590 & 156 & 3 & 11 & 1 & 0 \\
\hline Malta & 0 & 4 & 32 & 32 & 6 & 22 & 21 & 23 \\
\hline Greece & 2,103 & 472 & 2,494 & 1,759 & 1,034 & 368 & 113 & 439 \\
\hline Netherlands & 1,225 & 587 & 2,312 & 2,443 & 1,848 & 809 & 457 & 820 \\
\hline Others & 412 & 244 & 1,457 & 987 & 0 & 0 & 0 & 137 \\
\hline Australia & 412 & 244 & 1,457 & 987 & 0 & 0 & 0 & 137 \\
\hline Canada & 30 & 6 & 8 & 103 & 11 & 15 & 334 & 335 \\
\hline Korea & 195 & 276 & 862 & 554 & 859 & 228 & 124 & 248 \\
\hline Switzerland & 532 & 160 & 1,623 & 1,657 & 1,325 & 110 & 0 & 0 \\
\hline united Kingdom & 2,204 & 737 & 3,069 & 2,162 & 605 & 130 & 243 & 851 \\
\hline United State & 2,505 & 739 & 2,926 & 2,968 & 259 & 195 & 146 & 899 \\
\hline Others & 228 & 77 & 743 & 627 & 255 & 123 & 183 & 0 \\
\hline $\begin{array}{lll}\text { Emerging \& Dev. } & \text { \& } \\
\text { Economies } & & \end{array}$ & 9,266 & 5,090 & 13,144 & 7,470 & 2,893 & 3,180 & 3,333 & 4,693 \\
\hline Developing Asia & 6,405 & 2,822 & 10,119 & 4,173 & 1,011 & 1,227 & 430 & 1,861 \\
\hline Europe & 561 & 203 & 489 & 465 & 516 & 424 & 659 & 856 \\
\hline Turkey & 488 & 155 & 476 & 351 & 282 & 246 & 0 & 233 \\
\hline $\begin{array}{l}\text { Mid.East, N.Africa \& } \\
\text { Pakistan }\end{array}$ & 2,100 & 2,039 & 2,504 & 2,507 & 1,327 & 1,484 & 2,143 & 1,841 \\
\hline Sub-saharan Africa & 23 & 26 & 32 & 33 & 39 & 46 & 19 & 12 \\
\hline Western Hemisphere & 178 & 1 & 1 & 292 & $\mathbf{0}$ & $\mathbf{0}$ & 82 & 124 \\
\hline
\end{tabular}

Source: IMF 
Data on the geographical distribution of Libyan exports in the table (1), as well as the curve (2), showed the relative importance of the developed countries in the Libyan total exports and we noted the concentration of Libyan exports on a certain number of partners, where most of the trade exchange with these countries which accounted ( $80.4 \%)$, coming at the forefront of it, the Eurozone countries, which accounts for (65\%) of total Libyan exports to advanced economies through the years $2010-2017$ and formed about $(81.5 \%)$ from total export to advanced countries. We saw that the vast majority of Libya's oil exports going to Italy, Germany, Spain, France, and Britain (The main trade partner of Libya is the European Union), but the most important partners are Italy and Germany, then followed by the United States and the United Kingdom. The relative importance of Libyan exports to the developed countries due to the characteristics of their economies as industrial countries relies on crude oil. And Libyan exports to emerging and developing economies accounting for (19.6\%), and developing Asia accounted for (11\%) of the total Libyan exports, followed by exports to the Middle East, North Africa, Pakistan (6.2\%)\%). And the Western Hemisphere represents from Libyan total exports for (0.3\%), and Europe's countries which accounted (0.2) and Turkey comes at its front, followed by subSaharan Africa which represented (.09\%) from total Libyan exports. (Alhasadi, I. \& Alhasadi, A. 2018). Libyan oil exports to nearly all destinations plummeted in 2011 along with production, but have since revived at 2012. And then exports decline after 2012 to the first quarter of 2017 Then rose again in the Fourth quarter 2017according to information available to the economic bulletin of the Central Bank of Libya until 2018.

Figure (2): show the Geographical distribution of Libyan oil exports during (2010-2018)

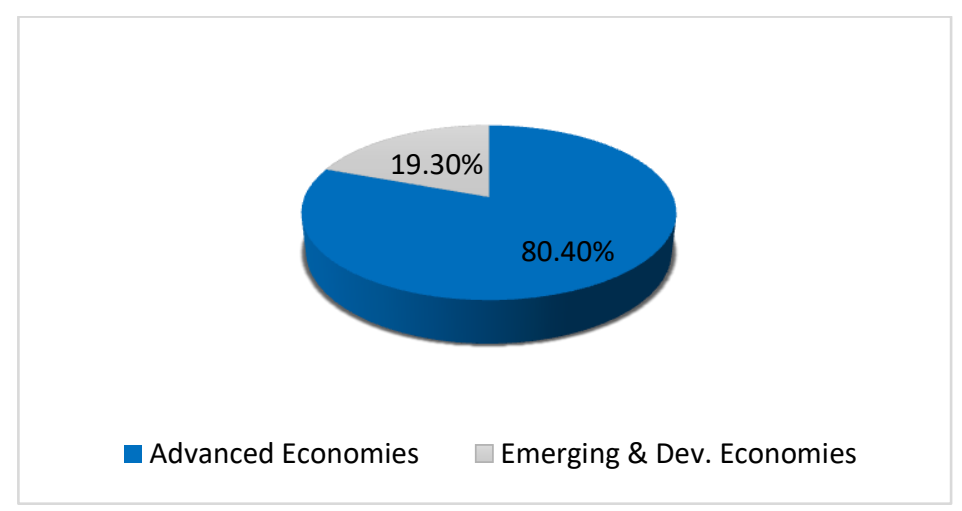

Researcher prepared.

\section{2-5. Analysis of structure of oil wealth exports and derivatives}

The oil sector is considered the main sector of Libya to obtain foreign currencies, and represent the main revenues of financing the public treasury and where the financial resources of oil are forming great importance in Libya and the state relies on oil revenues as a major source of funding for its development programs. It is natural that the overall economic performance depends on oil revenues and becomes vulnerable to the fluctuations in this sector.

Table (2) Development of the volume of Libyan oil exports during the period (2008-2018)

\begin{tabular}{|c|c|c|c|c|c|c|c|}
\hline Year & export of & $\begin{array}{c}\text { Crude } \\
\text { Oil } \\
\text { natural gas } \\
\text { Exports }\end{array}$ & $\begin{array}{c}\text { Petrochemical } \\
\text { and petrolum } \\
\text { derivatives } \\
\text { Export } \\
\text { thousand metric } \\
\text { tons" }\end{array}$ & $\begin{array}{c}\text { Total } \\
\text { exports }\end{array}$ & $\begin{array}{c}\text { Oil } \\
\text { Exports } \\
\text { Million } \\
\text { dinar }\end{array}$ & $\begin{array}{c}\text { Rate } \\
\text { Growth in exports }\end{array}$ & $\begin{array}{c}\text { Percentage } \\
\text { of oil } \\
\text { exports to } \\
\text { total exports }\end{array}$ \\
\hline 2008 & 1051.9 & 525.7 & 2393.2 & $77,027.0$ & $75,243.0$ & - & $\mathbf{9 7 . 8 \%}$ \\
\hline 2009 & 1035.5 & 478.2 & 2535.7 & $46,319.0$ & $44,626.0$ & $\mathbf{- 4 0 . 6 \%}$ & $\mathbf{9 6 . 3 \%}$ \\
\hline 2010 & $1,078.8$ & 491.1 & 2489.3 & $61,658.0$ & $59,850.0$ & $\mathbf{3 4 . 1 \%}$ & $\mathbf{9 7 . 0 \%}$ \\
\hline
\end{tabular}




\begin{tabular}{|c|c|c|c|c|c|c|c|}
\hline 2011 & - & 109.3 & 703.5 & $23,254.0$ & $22,789.0$ & $\mathbf{- 6 1 . 9 \%}$ & $\mathbf{9 8 . 0 \%}$ \\
\hline 2012 & 827.5 & 468.5 & 310.4 & $76,893.0$ & $75,335.0$ & $\mathbf{7 5 . 2 \%}$ & $\mathbf{9 7 . 9 \%}$ \\
\hline 2013 & 713.4 & 316.7 & 1001.2 & $58,442.6$ & $56,445.3$ & $\mathbf{- 2 5 . 0 \% \%}$ & $\mathbf{9 6 . 5 \%}$ \\
\hline 2014 & 742.1 & 124.5 & 819.6 & $24,511.0$ & $22,951.4$ & $\mathbf{- 5 9 . 3 \%}$ & $\mathbf{9 3 . 6 \% +}$ \\
\hline 2015 & 787.5 & 109.0 & 869.8 & $14,996.9$ & $13,853.2$ & $\mathbf{- 3 9 . 6 \%}$ & $\mathbf{9 2 . 3 \%}$ \\
\hline 2016 & 775.9 & 111.3 & 667.2 & $9,402.0$ & $8,676.0$ & $\mathbf{- 3 7 . 3 \%}$ & $\mathbf{9 2 . 2 \%}$ \\
\hline 2017 & 865.3 & 287.7 & 240.6 & $\mathbf{2 6 , 2 2 1 . 7}$ & $\mathbf{2 4 , 9 1 0 . 7}$ & $\mathbf{1 8 7 . 1 \%}$ & $\mathbf{9 5 . 0 \%}$ \\
\hline
\end{tabular}

Source: National Oil Corporation. * Estimated data.

- Planning Secretariat, National Information and Documentation Authority, Foreign Trade Statistics.

- Central Bank of Libya, annual reports, multiple issues. - Calculated percentages.

The table (2) above shows the Libyan oil exports (crude oil, natural gas, and petrochemical, petroleum derivatives) during the period 2008-2018. Libya's oil production and exports have been affected by the international fluctuations in oil prices and production and civil unrest over the past years. We noted that the oil production fell hence the decline of oil exports in 2009 due to oil price fluctuations and OPEC's decision to reduce production in response to the global crisis, after that it increased on 2010. In 2011 oil production and exports suffered from disruptions where the minimal-level of production and that which mostly intermittent output was consumed locally thus, oil exports in 2011 recorded a sharp decline of $61.9 \%$ from 2010. And this oil shock led to the collapse of the Libyan economy, where all economic sectors were affected by it. The oil sector recovered during the year 2012 and increased production by 200\%, but it was below its pre-war levels, as a result of this increase increased oil exports by $75.2 \%$. However, exports returned again and recorded a decline by (25\%) in 2013. But the biggest crisis witnessed by the Libyan oil sector and with him, the economy of the country fell by unprecedented in 2014, 2015 Only as a result of the deterioration of international oil prices and the decline in Libyan production. Despite the agreement on the opening of oil's ports, but the Libyan economy is still threatened because oil prices are falling sharply due to several reasons, the most important oil smuggling and low price in the black market, the increase the global supply of oil over demand for several reasons, the most important one increase Iran's oil production due to lifting sanctions imposed on it, replace traditional energy sources with alternative ones such as solar, nuclear, wind and other. and coincided with the discovery of large amounts of shale oil in the United States (Libyan Organization for Policies and Strategies, 2016). That caused severe damage to the Libyan economy, this sharp decline was represented as following proportions respectively (59.3\%), (39\%), reflecting the continuing turmoil in oil production as a result of the blockade of several major eastern oil ports as well as protests in oil fields and pipelines in the western region. The decline in oil exports continued until 2016 and this decline in oil exports the proportion (37\%). Oil production recovered only in 2017 oil export recorded relatively stability, where the rate of growth in oil exports about (187\%). In addition, table (2) above shows that oil exports represent a high percentage of total Libyan exports, where the oil exports represent percentage ranging from $92.3 \%$ to $98.0 \%$ in the years from 2008 to 2017 . For the year 2018, we were unable to obtain the information from published economic reports or Central Bank publications.

\section{2-6. The impact of oil export volatility on real gross domestic product of Libyan economic}

The size and structure of exports to each country are linked to the production base of this country and since Libya enjoys abundant oil resources, it is natural that oil represents the largest proportion of Libyan exports. In order to determine the volume of oil exports and their relation to GDP and their impact on it, it necessary to analyse the following:

Table (3) The impact of oil export volatility on real gross domestic product by Economic Sectors at Constant Prices

In Millions of LYDs

(At constant prices 2007) 


\begin{tabular}{|c|c|c|c|c|c|c|c|c|}
\hline Economic sectors & 2008 & 2009 & 2010 & $2011^{*}$ & $2012 *$ & 2013 & 2014 & $\begin{array}{r}2015- \\
2018\end{array}$ \\
\hline $\begin{array}{l}\text { Agriculture,hunting,fore } \\
\text { stry and Fishing }\end{array}$ & 636,8 & 648.7 & 642.0 & 180.9 & 248.1 & - & - & - \\
\hline $\begin{array}{l}\text { Extraction of crude oil } \\
\text { and natural gas }\end{array}$ & $\begin{array}{l}55,591 . \\
6\end{array}$ & $\begin{array}{l}51,712 . \\
7\end{array}$ & $\begin{array}{l}52,943 . \\
1\end{array}$ & $\begin{array}{l}15,492 . \\
6\end{array}$ & $\begin{array}{l}38,511 . \\
3\end{array}$ & - & - & - \\
\hline Mining and Quarrying & 285.1 & 279.9 & 294.9 & 61.4 & 86.0 & - & - & - \\
\hline Manufacturing industry & $3,205.5$ & $3,487.3$ & $33,44.0$ & 704.3 & $2,353.1$ & - & - & - \\
\hline Electricity,gas and water & 790.1 & 814.3 & 796.9 & 410.4 & 926.3 & - & - & - \\
\hline $\begin{array}{l}\text { Building and } \\
\text { constructions }\end{array}$ & 3.418 .4 & 3.839 .9 & 4.053 .3 & 852.8 & 954.5 & - & - & - \\
\hline $\begin{array}{l}\text { Wholesale and retail } \\
\text { Trade, Goods \& Vehicle } \\
\text { Repair }\end{array}$ & 3.063 .7 & 3.224 .8 & 3.434 .4 & 1.283 .6 & 2.397 .0 & - & - & - \\
\hline Hotels and resturents & 124.2 & 132.6 & 140.7 & 26.8 & 22.1 & - & - & - \\
\hline $\begin{array}{l}\text { Transport, Storage } \\
\text { andtelecommunications }\end{array}$ & 579.7 & 616.4 & 657.2 & 279.7 & 333.2 & - & - & - \\
\hline Financial intermediary & $3,959.1$ & $4,206.3$ & $4,433.5$ & $2,380.2$ & $3,168.9$ & - & - & - \\
\hline $\begin{array}{l}\text { Real-estate and renting } \\
\text { and business activities }\end{array}$ & 191.5 & 231.2 & 279.9 & 161.7 & 229.3 & - & - & - \\
\hline $\begin{array}{l}\text { Government,defense } \\
\text { and mandatory social } \\
\text { insurance }\end{array}$ & $5,583.0$ & $5,750.5$ & $5,903.8$ & $6,034.5$ & $7,470.3$ & - & - & - \\
\hline Education** & 441.6 & 673.6 & 680.4 & 190.7 & 371.3 & - & - & - \\
\hline $\begin{array}{l}\text { Health care and social } \\
\text { activies } * *\end{array}$ & 305.5 & 372.7 & 381.2 & 386.0 & 502.5 & - & - & - \\
\hline Other services & $2,344.3$ & $2,352.3$ & $2,460.1$ & $1,138.2$ & $1,822.6$ & - & - & - \\
\hline $\begin{array}{l}\text { Financial services } \\
\text { indirectly computed (_) }\end{array}$ & $\begin{array}{l}- \\
3,773.4\end{array}$ & $\begin{array}{l}- \\
4,002.1\end{array}$ & $\begin{array}{l}- \\
4,254.1\end{array}$ & $\begin{array}{l}- \\
2,296.4\end{array}$ & $\begin{array}{l}- \\
3,041.4\end{array}$ & - & - & - \\
\hline $\begin{array}{l}\text { GDP in the basic price } \\
\text { distributed between }\end{array}$ & $\begin{array}{l}76,746 . \\
7\end{array}$ & $\begin{array}{l}74,341 . \\
1\end{array}$ & $\begin{array}{l}76,191 . \\
5\end{array}$ & $\begin{array}{l}27,287 \\
4\end{array}$ & $\begin{array}{l}56,355 . \\
1\end{array}$ & $\begin{array}{c}39,01 \\
6.3\end{array}$ & $\begin{array}{l}20,38 \\
8.2\end{array}$ & - \\
\hline Groth rate in GDP & $-1.8 \%$ & $-3.1 \%$ & $2.4 \%$ & $-64.1 \%$ & $106.5 \%$ & $\begin{array}{c}- \\
30.7 \\
\%\end{array}$ & $-47 \%$ & - \\
\hline $\begin{array}{l}\text { Extraction of crude oil } \\
\text { and natural gas }\end{array}$ & $\begin{array}{l}56,114 . \\
1\end{array}$ & $\begin{array}{l}53,255 . \\
7\end{array}$ & $\begin{array}{l}53,872 . \\
4\end{array}$ & $\begin{array}{l}16,499 . \\
9\end{array}$ & $\begin{array}{l}41,001 . \\
5\end{array}$ & $\begin{array}{c}24,71 \\
0.6\end{array}$ & $\begin{array}{l}9,777 \\
.6\end{array}$ & - \\
\hline
\end{tabular}




\begin{tabular}{|l|l|l|l|l|l|l|l|c|}
\hline $\begin{array}{l}\text { Other economic } \\
\text { activities }\end{array}$ & $\begin{array}{l}20,632 . \\
6\end{array}$ & $\begin{array}{l}21,085 . \\
4\end{array}$ & $\begin{array}{l}22,319 . \\
1\end{array}$ & $\begin{array}{l}10,787 . \\
5\end{array}$ & $\begin{array}{l}15,353 . \\
6\end{array}$ & $\begin{array}{c}14,30 \\
5.6\end{array}$ & $\begin{array}{l}10,61 \\
0.6\end{array}$ & - \\
\hline $\begin{array}{l}\text { the ratio of Extraction } \\
\text { of crude oil and natural } \\
\text { gas to GDP }\end{array}$ & $73.1 \%$ & $71.6 \%$ & $70.7 \%$ & $60.4 \%$ & $72.7 \%$ & $\begin{array}{c}63.3 \\
\%\end{array}$ & $\begin{array}{l}47.9 \\
\%\end{array}$ & - \\
\hline $\begin{array}{l}\text { The ratio of other } \\
\text { activities }\end{array}$ & $28.88 \%$ & $28.3 \%$ & $29.2 \%$ & $39.5 \%$ & $27.2 \%$ & $\begin{array}{c}36.6 \\
\%\end{array}$ & $\begin{array}{l}52.0 \\
\%\end{array}$ & - \\
\hline
\end{tabular}

Source: Ministry of Planning.

*Preliminary data.

**Representative of the Private and Public Sectors

The preliminary data on the real gross domestic product (GDP) issued by the Central Bank of Libya through the annual report for 2018, showed that the GDP in (2008) has reached 76746.7 billion dinars and recording growth rate of GDP declined and reached during 2008 about $(-1.8 \%)$. And as for with regard to the contribution of economic activities to real GDP the extraction activities oil and natural gas in GDP accounted the largest contribution it about, 56,114.1 billion dinars, accounting for 73.1\%, while the rest of the other economic sectors contribution about 20,632.6 billion dinars, which is accounted for 26.88\% in real GDP. The period of (2009) we note has decreased GDP to 74,341,1 billion dinars, and the decline rate was (3.1\%), in addition, the decline of the contribution of the oil sector in the GDP and the increase in the contribution of the non-oil sectors especially in the construction sector due to the large boom witnessed by the sector through the initiation of an infrastructure project in (2009). in this period the oil production and export and its proportion in GDP declined due to several factors most important global oil markets were affected by the global financial crisis and the prices of crude oil fell causing a decline in the production and export of oil which in turn reflected in Libya. And the main reason for the decline in the contribution in GDP of the oil and natural gas sector is OPEC's decision to cut production to try to balance the oil market forces affected by the global financial crisis. So natural gas extraction activities decline into 53,255.7, while the rest of the other economic sectors continued in increasing and reach to 21,085.4. In 2010 the GDP reached 76,191.5 billion dinars at constant prices (2007 prices), with a growth rate of $2.4 \%$, and there is no information about the GDP after 2014. The period from 2011 - 2018, there was a significant fluctuation in the production and export of oil in Libya because of internal political and security conditions which affected the production process in Libya, which their effects reflected on the different productive sectors and on the size of their contribution to the gross domestic product and the contribution of the oil and natural gas sector in the GDP. The Libyan economy collapsed in the wake of the popular uprising in February 2011 As the war raged, witnessed all economic activities, a dramatic decline virtually especially oil production and exports (the mainstay of the Libyan economy). A consequence, total real GDP in 2011 was 64 percent lower than in 2010, Whereas there was some recovery in 2012 when the war ended and oil production came back faster than expected, but the economy has not yet reached a point of sustained longer-term in economic growth. Where the growth in GDP reached to $106 \%$. In fact, in 2013 the economy has only just got back to what it was through the uprising where total GDP declined in 2013 (30) percentage, due to the decline in oil and gas production and exports, which negatively affected GDP and caused a decline of it. But the economy returned to a relapse again in 2014 because the oil fields were exposed to the combustion and the destruction that resulting in the closing of oil fields through the war in the eastern Libyan and that cues decline in oil production and exports and reflected on GDP, and led to decreased it in 2014 where it was 47 percent lower than in 2013. Data on GDP were not available after 2014 through the Central Bank of Libya (CBL).

\section{Conclusion and Recommendation}

The study concluded that the Libyan economy is heavily dependent on the oil sector, where it is Significantly based on its revenue, these revenues are the main engine of the economy, where the crude oil and natural gas representing about 
$92 \%, 62 \%, 77.5 \%, 85.9 \%$ and $93.2 \%$ of the general government revenues through the years $2014,2015,2016,2017$ and 2018 respectively, and about $95 \%$ of total exports and $75 \%$ of gross domestic product, which is reflected negatively on the economy and perhaps the security conditions witnessed by the oil sector in 2011 . The export sector also suffers from the phenomenon of geographic concentration of exports, which makes it vulnerable to fluctuations in the markets of those countries, the years witnessed the years 2014 and 2015 the sharp decline in oil prices in international markets, the subsequent decline in the value of the Libyan dinar, rising prices, the shrinking economy, the decline in the revenues of foreign exchange, government revenues and GDP is proof of that. We summarize a set of recommendations are:

$>$ Adopting a comprehensive strategy to reduce reliance on the oil sector by directing large investments to various non-oil economic sectors, which would create new jobs and opportunities for individuals.

$>$ Libya needs to improve managing the oil-producing and exporting, needs to cushion the effects on the economy from booms and busts in the oil market and, over the longer term must take account of issues of intergenerational equity in mapping out strategies for government spending, investment, and financing of public sector operations.

$>$ Diversification of export markets and the elimination of the phenomenon of geographical concentration, which makes exports hostage to the conditions of demand and volatilities in those markets.

$>$ A much is needed to help diversify the economy through a comprehensive approach, remove obstacles to developing the non-oil sector.

$>$ Reducing dependence on oil would also require establishing modern tax policy structures and tax administrations.

\section{References}

1. Abu Ghalia, M, S. \& Al-Fahal, H. (2012). Oil exports and their relationship to the rate of the economy's openness with the outside world: An analytical study during the period 1995-2008. Journal of Al - Quds Open University for Researches and Studies, (2), No. 27.

2. Ahmouda, M. (2014). The Impact of oil Exports on Economic Growth: The Case of Libya, Doctoral Thesis, Czech University of Life Sciences Prague, Faculty of Economics and Management, Department of Economics.

3. Central Bank of Libya, annual reports2007-2018.

4. Economic Bulletin Central Bank of Libya 2018 - Fourth Quarter.

5. Elbeydi, K, R.M; Hamuda, A M. and Gazda, V. (2010). The Relationship between Export and Economic Growth in Libya Arab Jamahiriya, Theoretical and Applied Economics, Volume XVII (2010), No. 1(542).

6. Elhusadi, I. \& Alhasadi, A. (2018). The impact of petroleum revenues on the Libyan economy during the period (20062017), Second Scientific Conference of Oil and Gas 2018.

7. Imhanna, M. E. (2016). The Relationship between Exports and Economic Growth: An Analytical Theory Study in Libya 1980-2010, amarabac, vol (7), N (20).

8. Libyan Organization for Policies and Strategies (2016), the reality of Libyan oil and the economic and social effects of its export moratorium. http://loopsresearch.org/projects/view/106/?lang=ara

9. Shamia, A. A. (1991) entitled as Libyan exports and its role on the economy: Applied theory study (1980-1990). Journal of Economic Research, vol (3), issue (2), Benghazi.

10. U.S. Energy Information Administration. (2015). Country analysis brief: Libya.

11. Yahia, A. \& Metwally, M. M. (2007). Impact of fluctuations in oil prices on Libyan economic growth. Middle East Business and Economic Review, 19 (1), 39-55.

12. Vohra, R. (2001). Export and economic growth: Further time -series evidence from less-developed countries. International Journal in Economic Research, 7(3),345-350.http://dx.doi.org./10.1007/BF02295403. 